\title{
Do Jordanians really speak like Palestinians?
}

\author{
BRUNO HERIN (Bruxelles)
}

\begin{abstract}
A common belief is that Jordanian Arabic is mostly similar to Palestinian Arabic. It will be shown that although the dialects of the eastern and western bank of the Jordan river are rightly classified as Southern Levantine, there is compelling linguistic evidence that the sedentary varieties spoken in Jordan did not originate from Palestine, but rather from the North, more precisely from Ḥōrān, an ancient settlement area of the Levant located between what is now Jordan and Syria.
\end{abstract}

Key-words: Arabic dialectology, Jordan, Palestine, Salt, Ḥōrān, classification.

\section{Introduction}

A very common impression is that the kind of Arabic spoken in Jordan is almost identical to that spoken in Palestine and that despite small differences, Jordanians and Palestinians speak more or less the same dialect. This feeling is of course not totally unfounded since the primary input of the dialect of Amman, the capital of Jordan, is urban Palestinian (see AL-WER 2007 for the formation of the dialect of Amman). While collecting linguistic data in Salt (now a small town near Amman but once one of the biggest towns in the area), unexpected features were encountered, raising the issue of the true nature of this dialect. Since then, this has been the subject of numerous exchanges with Enam AL-WER, who, being a native speaker of both Salti and Hōrāni, pointed out that her intuition was that the dialect of Salt was essentially Hōrāni, in this way challenging the common view that Jordanian Arabic is most closely related to the varieties spoken on the other side of the Jordan River. The purpose of this article is to test this claim by contrasting linguistically Salti, Hōrāni and a rural dialect of the West-Bank.

Salt is located $25 \mathrm{~km}$ northwest of Amman, the capital of Jordan and is now the administrative centre of al-Balqā' region. It now has a population of 71100 inhabitants and is considered to be Central Jordan. The Palestinian data originates from Ğalbūn, a Palestinian village located $20 \mathrm{~km}$ East of Jenin. Hiōrān is an area that starts $12 \mathrm{~km}$ south of Damascus going southward until the district of 'Ağlūn in Northwest Jordan. It may seem questionable to compare things that do not belong to the same category. We have on the one hand two dialects clearly identifiable (Salti and Ğalbūni), but on the other hand a group of dialects delimited geographically by an area (Hōorān). Here is what CANTINEAU says about the dialects of Ḥōrān: 
Dès la fin de 1934, j'avais reconnu, grâce à ces enquêtes, que les parlers ḥōrânais était fort semblables entre eux, que leur masse homogène constitue l'extrême pointe, en territoire syrien, des parlers transjordaniens, et qu'ils sont entourés au Nord, à l'Est et à l'Ouest, par des parlers de sédentaires et de nomades de types tout différents. 1

Two things ought to be noted in this statement. The first one is the strong homogeneity of Hōrāni dialects, which makes it possible to consider them a single variety, and thus suitable for comparison with other more localised dialects. The second thing is that, according to CANTINEAU, Hōrāni dialects constitute the most northern end of Jordanian dialects.

As far as Jordanian dialectology is concerned, one should note that very few scholars have shown interest in it. Until very recently, no comprehensive description of any Jordanian variety was available to us. ${ }^{2}$ The first to approach the dialectology of Jordan is BERGSTRÄSSER (1915) in his linguistic atlas of Syria and Palestine. From a typological point of view, CLEVELAND (1963) was the first to classify the dialects of Jordan (including the two banks of the Jordan River) into four groups according to the way those dialects express "he says": yigūl (Bedouin), bigūl (sedentary Transjordanian, south of the West Bank and Jordan river), bikūl (rural dialects around Jerusalem and in the central and northern part of the West Bank). The last group is called $b i$ ' $\bar{l} l$ and refers mainly to urban varieties. This terminology highlights two features. The first one is the use of the prefix $b$ to express the indicative imperfective, and the second is the realisation of Old Arabic */q/. As far as Transjordan is concerned, only yig $\bar{u} l$ and big $\bar{u} l$ are traditionally found. The bik $\bar{u} l$ (rural Palestinian) and $b i^{\prime} \bar{u} l$ (urban) types were imported from Palestine. The main split is thus between the sedentary varieties which possess the prefix $b$ - and the Bedouin varieties which lack it. The phonology of these two types is largely similar: the interdentals have been maintained, */ḍ/ and */ḍ/ merged into $/ \underline{d} /$ and $* / \check{g} /$ is realised as an affricate. The affrication of $* / \mathrm{k} /$ cannot be used as a feature to distinguish Bedouin from sedentary dialects as it is usually found in both sedentary and Bedouin varieties in the centre and the north of Jordan. The southern sedentary and Bedouin dialects lack the affricate. The affrication of $* / \mathrm{k} /$ could then only be used to separate southern varieties from northern ones. The scholar who wrote probably the most about Jordanian dialectology is Heikki PALVA. In his first attempt to reconsider CLEVELAND's classification of the dialects of Jordan and Palestine (PALVA 1984), he reaches the conclusion that the sedentary dialects should be divided into urban $\left(b i^{\prime} \bar{u} l\right)$ and rural. He divides the rural varieties into five groups, three in Palestine ( $b i k \bar{u} l$, centre of Palestine; biqūl, free of any Bedouin influence, and the dialects of the South which share many features with the Bedouin surrounding varieties) and two in Jordan (central and northern dialects, and southern dialects). The main difference between these two groups is the presence of the affricated reflex of $* / \mathrm{k} /$ in the North, whereas southern dialects lack it. PALVA also mentions the close ties between the dialects of central Jordan and Hōrāni dialects. The first scholar who pointed out the proximity of Jordanian and Horāni dialects is CANTINEAU (1946: 71, 123-124). The relation between the dialect of Salt and the surrounding Bedouin dialects has also been

1 CANTINEAU 1946: 71.

2 For the first comprehensive description of a Jordanian dialect, see HERIN 2010. 
investigated by PALVA in a couple of his articles (PALVA 1992, 1994 and 2008). He concludes that "...during the first centuries of the Ottoman era Salti was a rural sedentary dialect that was heavily influenced by neighbouring Bedouin dialects" (PALVA 1994: 463). The features he considers to be of Bedouin origins are the voiced reflex [g] of */q/, affricated reflex [č $]$ of $* / \mathrm{k} /$, maintenance of gender distinction in $2^{\text {nd }}$ and $3^{\text {rd }}$ plural and some lexical items like gōtar "to go", ladd "to watch" or sōlaf "to tell". As for the sedentary features of the dialect of Salt, PALVA notes for example the double negation $m \bar{a}$...šs about which he says that "...it is an older, 'genuine' trait and seems to have preserved its original affective value" (PALVA 1994: 469). ${ }^{3}$

Since the relations between the sedentary and the Bedouin features in the dialect of Salt have been to a large extent accounted for, what clearly remains to be done is to contrast the dialect of Salt with other sedentary varieties. The focus of this article will therefore be on the ties between the dialect of Salt, Hōrāni dialects and the dialect of Ğalbūn (a small village the area of Jenin, a good example of rural Palestinian). Data from Salt were collected in situ from 2005 until 2007 (HERIN 2010), whereas the Ğalbūni data come from direct elicitation with a consultant native of this village. As far as Hōrāni dialects are concerned, three sources can be used: CANTINEAU's description (CANTINEAU 1940 and 1946), BANI-YASIN and OWENS' article on the phonology of a northern Jordanian dialect (BANI-YASIN / OWENS 1987) and BEHNSTEDT's linguistic atlas of Syria (BEHNSTEDT 1997). Since a systematic comparison is beyond the scope of the present work. only some features in phonology and morphology will be treated. In phonology, the following features will be discussed: the realisations of Old Arabic $* / \mathrm{q} /$ and $* / \mathrm{k} /$, assimilations, secondary velarisation, the quality of epenthetic vowels and the phonetics of the feminine ending. In morphology, the investigation will be limited to the reflexes of the Old Arabic stems ${ }^{*} \mathrm{CaC} \overline{\mathrm{C}} \mathrm{C}$ and ${ }^{*} \mathrm{CaCu} \mathrm{C}$, free and bound pronouns and two points in verbal morphology: verbs whose first consonant is weak and form IV.

\section{Phonology}

\subsection{Reflexes of $* / \mathbf{q} /$ and $* / \mathbf{k} /$}

As far as the consonantal inventory is concerned, one should note that the three dialects investigated here share many similarities: all of them retained the interdentals $/ \mathbf{d} /, / \underline{t} /$ and $/ \mathrm{d} /, * / \mathrm{d} /$ and $* / \mathrm{d} /$ merged into $/ \mathrm{d} /$, and $* / \check{\mathrm{g}} /$ is realised as I.P.A. [d]]. The main differences lie in the reflexes of $* / \mathrm{q} /$ and $* / \dot{\mathrm{k}} /$. The dialect of Ğalbūn, like many other rural Palestinian varieties has a voiceless palatal $/ \mathrm{k} /$ realisation of $* / \mathrm{q} /$ and an unconditioned affrication of */k/ whose reflex is usually /č/ in all positions, as shown in the following examples:

*/q/ $\rightarrow$ /k/: yikdar "he can", kult "I said", kalb "heart", bakara "cow", kadim "old", baka "he was", kirn "horn", rakabe "neck", ka'ad "he sat down", wiki "he fell", wakkaf wikif "he stopped", kaddēš "how much", kallāye "frying pan", durṛāk "peach"...and many more. The shift from */q/ to /k/ in the dialect of Ğalbūn appears to have occurred

3 Negation strategies in the dialect of Salt have been studied more thoroughly by the same author in PALVA 2004. 
everywhere. The uvular could be at best rendered by the consultant by a somehow backer $[\mathrm{k}]$ in loans from standard Arabic, but never [q]. ${ }^{4}$

$* / \mathrm{k} / \rightarrow \mid \check{c} /$ : račad "he ran", čțìr "many", bučra "tomorrow", ričbe "knee", čitf "shoulder", čabš "male sheep", yimsičc "he grabs", čū "elbow", $\check{c} a c b$ "heel", mčarsah "paralysed", ifčah "limping", mačatte "ashtray", samače "fish". These examples show that the passage from $* / \mathrm{k} /$ to $/ \check{c} /$ appeared in all contexts, even in the vicinity of back vowels $($ bučra and $\check{c} \bar{u}$ ). Unlike */q/, there are however a few exceptions in which the occlusive realisation of $* / \mathrm{k} /$ was maintained, like in the roots $k-t-b$ "to write" (yiktibu "they write") and '-k-l "to eat" ( $a k a l$ "he ate", yōkil "he eats", kul "eat!"). Etymological $* / \mathrm{k} /$ was also preserved in the $2 \mathrm{~ms}$ and $2 \mathrm{mp}$ bound pronouns $-a k$ and $-k u m$ as opposed to the feminine forms -ič and -čin.

As for Salti and Hōrāni dialects, the consonantal inventory is exactly the same. The main reflex of */q/ is /g/: yigdar, gul(i)t (realised gulı (u)t in Ḥōrān), bagaṛa, gadìm, baga, girn (also used in Jordan for a man who is too permissive with his wife), ragaba, ga'ad, wigi', wigif, gaddēš, gallāye, durrrāg. An unvoiced reflex of */g/ can appear in Salti in some roots like $k$-t-l "to kill, to beat up" (katal "he killed", maktūl "killed", nkatal "he got killed") or $w$-k-t (wakt "time", mwakkat "temporary"). The devoicing of /g/ was of course triggered by the proximity of the voiceless consonant /t/. Salti and Hōrāni have two reflexes of etymological $* / \mathrm{k} /: / \mathrm{k} /$ and $/ \check{c} /$. In both varieties, $/ \mathrm{k} /$ and $/ \check{c} /$ established themselves as independent phonemes as shown by the following minimal pairs: čêf "how?"/ kēf "pleasure"; rāčcib "riding" / rākib "passenger"; čib ${ }^{i} r$ "kind of cloth" / kibir "he grew up". In both Salti and Hōorāni, the affricate usually surfaces in front contexts (front vowels $/ \mathrm{i} /, / \mathbf{1} /$, $/ \mathrm{e} /, / \mathrm{e} /$, and front allophones of $/ \mathrm{a} / \mathrm{an} / \overline{\mathrm{a}} /$ ). The following examples are found in Salt and Ḥōrān: had $\bar{d} \bar{c}$ "this (f.)", činne "daughter-in-law", hèc "so", čaff "palm", člāb "dogs". Strangely enough, the affricate can also be found in the vicinity of back vowels both in Salt and Ḥōrān. CANTINEAU gives the example of dīc "cock" whose plural is dyūč and which was also recorded in Salt. For Ḥōrān, other examples are given by BANI-YASIN / OWENS (1987: 298), such as čol "open area" and the verb čaxx bučuxx "he slaughters". The word $\check{c} \bar{o} l$ is obviously a loan from Turkish (çöl "desert"), so it cannot account for a case of affrication in back context. As for the verb čaxx bučuxx, it was not recognised by the Salti consultants. CANTINEAU notes that the maintenance of $/ \mathrm{k} /$ in Ḥōrāni is approximately twice and a half more frequent than its affrication into /č/ (CANTINEAU 1946: 122). This statement tallies with what was recorded in Salt in terms of the frequency of the affricate. Generally speaking, all the examples of affrication given by CANTINEAU could also be found in Salt. The only difference concerns the roots $k-b-r$ "to grow big" and $k-\underline{t}-r$ "to be numerous" which are never affricated in Salt but for which CANTINEAU gives affricated reflexes, although he notes than in some parts of Ḥōān these roots are not affricated. To illustrate further the differences between rural Palestinian and Salti/Hōrāni as far as /č/ is concerned, it can be added that all the Ğalbūni words mentioned above in which the affricate appears are realised in Salt and Ḥōrān with /k/ (all but one since čitf is also

4 Of course no one can be absolutely sure that $/ \mathrm{k} /$ in rural Palestinian came from uvular $/ \mathrm{q} /$ and not voiced $/ \mathrm{g} /$. It is assumed here that it came from /q/ as the uvular stop can still be found in some areas in Palestine. 
realized čit(i)f in Salt and Hōrān). Whereas the passage from */k/ to /č/ is (almost) systematic and unconditioned in rural Palestinian, /č/ has a root based lexical distribution in Salti and Hōrāni. This clearly shows that the Salti and the Hōrāni systems are essentially the same, whereas rural Palestinian behaves differently.

\subsection{Assimilations}

Assimilations are very common in Arabic dialects (and cross-linguistically). It comes thus as no surprise that many are shared by the three varieties investigated here. However, some of these assimilations, although extremely frequent in the traditional dialect of Salt and in Hōrāni, are not found in Ğalbūni, as exemplified below:

\begin{tabular}{|c|c|c|c|c|}
\hline & Salt & Ḥōrān & Ǧalbūn & \\
\hline $\ln \rightarrow \mathrm{nn}$ & gunna & gunna & gulna & (gulna "we said") \\
\hline \multirow[t]{2}{*}{$\mathrm{nl} \rightarrow \mathrm{ll}$} & bigullilli & llām & nlām & (nlām "he was blamed" \\
\hline & & & & bigūlin-li "they (f.) tell me) \\
\hline tš $\rightarrow$ Šs̆ & $b i \check{s} \check{s} \bar{u} f$ & biššu $f$ & bitšū $f$ & (bitšsuff"you see") \\
\hline ' $\mathrm{h} \rightarrow \mathrm{h} h \underline{\mathrm{C}}$ & maḥha & maḥha & ma'ha & (ma'ha "with her") \\
\hline
\end{tabular}

Another peculiar feature of both Salti and Hōrāni is that $/ \mathrm{h} /$ assimilates to a preceding voiceless consonant at morpheme boundaries. This could not be observed in Ğalbūn:

$\begin{array}{lll} & \text { Salti/Hōōāni } & \text { Ğalbūn } \\ \text { binit-hum "their daughter" } & \text { binittum } & \text { binithum } \\ \text { šăf-hum "he saw them" } & \text { šāffum } & \text { šăfhum }\end{array}$

Another point that puts Salti and Hōōāni together is the tendency to de-affricate $/ \breve{\mathrm{g}} /$ and $/ \check{\mathrm{c}} /$ before alveolar and dental consonants, whereas this process was not observed in Ğalbūn:

\begin{tabular}{|c|c|c|c|c|}
\hline \multirow[t]{2}{*}{ Salti: } & hadī̄čt il-marrra & "last time" & $\rightarrow$ & had \\
\hline & $\check{g} d \bar{a} d$ & "new (pl.)" & $\rightarrow$ & $\check{z} d \bar{a} d$ \\
\hline \multirow[t]{2}{*}{ Hōrāni: } & biričti & "my pond" & $\rightarrow$ & birišti \\
\hline & yiğlub & "he brings" & $\rightarrow$ & yižlub \\
\hline \multirow[t]{2}{*}{ Ğalbūn: } & biričti & “my pond" & $\rightarrow$ & biričti \\
\hline & $\check{g} d \bar{l} d$ & "new" & $\rightarrow$ & $\check{g} d \bar{l} d$ \\
\hline
\end{tabular}




\subsection{Secondary emphasis and epenthesis}

As far as secondary emphasis is concerned, the three dialects seem to show different patterns. On a scale, Hōorāni would be on top in terms of items showing inherent secondary emphasis, Ğalbūn at the bottom, and Salt somewhere in between. Consider the following items:

\begin{tabular}{|c|c|c|c|c|c|}
\hline Ḥōrān: & galb "heart" & $x \bar{l} l a$ "aunt" & $g \bar{a} l$ "he said" & ḅaggal "mule" & gabur "grave" \\
\hline Salt & galb & $x \bar{a} l a$ & $g \bar{a} l$ & bagal & gabir \\
\hline Šlbūn: & kalb & xāle & $k \bar{a} l$ & bagagl & kabir \\
\hline
\end{tabular}

Connected to secondary emphasis is the quality of epenthetic vowels. Levantine dialects in general insert epenthetic vowels to resolve consonant clusters that may occur after the elision of unstressed high vowels ( $\mathrm{CCvC} \rightarrow \mathrm{CCC} \rightarrow \mathrm{CvCC}:$ búg'udu "they stay" $\rightarrow$ $b^{\prime}$ g'd $^{\prime} \rightarrow$ búgu'd ) or to avoid initial and final CC clusters ( $g b \bar{a} l$ "in front of" $\rightarrow i g b \bar{a} l$, bint "girl" $\rightarrow$ binit). The unmarked quality of this epenthetic vowel is $i$ (I.P.A. [I]). In both Salti and Ğalbūni, the vicinity of $/ \mathrm{u} /$ is not enough to trigger a vowel harmony and move the epenthetic vowel to the back: xubiz-ha "her bread", ruhit "I went", gulit "I said" (kulit in Ğalbūn). The epenthetic vowel is pushed to the back only in the vicinity of a back consonant (although not pharyngeal, see ruhit): šug ul "work", hukum "rule" and for Salt also 'ugub "after", mugiur "caves", rukubto "his knees". In Ḥōrāni dialects, the vicinity of $/ \mathrm{u} /$ is enough to push the epenthetic vowel to the back: xubuz-ha "her bread", ruhut "I

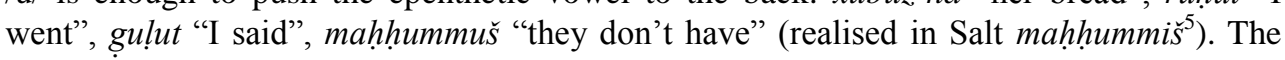
same thing happens in the vicinity of an emphatic (primary or secondary). Contrast Salti and Ḥōrāni (/i/ in an emphatic context tends to be centralised towards I.P.A. [i] in Salt):

\begin{tabular}{|c|c|c|}
\hline Ḥōrāni & Salti & \\
\hline buraḅbțt-ullhā-š & $b(i) r a b b t+-i l h \bar{a}-\check{s}$ & "he won't tie for her" \\
\hline gattui & gatțic & “cut!" \\
\hline gabur & gabir & "grave" \\
\hline raguss & ragiss & "dancing" \\
\hline galub & galib & "heart" \\
\hline
\end{tabular}

5 The underlying form is $m a-h u m-\check{s}$ (with-3mp-NEG). The cluster ' $h$ becomes $h h$ by way of reciprocal assimilation, and the final $/ \mathrm{m} /$ of the $3 \mathrm{rd}$ person plural pronoun -hum is geminated when followed by the negation marker $-\check{s}$. An epenthetic vowel is then inserted to resolve the final CC cluster. 


\subsection{Phonetics of feminine ending - $a$}

As it is well documented, most Levantine dialects raise the feminine ending $-a$ in nonemphatic and non-guttural contexts. ${ }^{6}$ It is usually raised to I.P.A. [e], but in some cases, raising goes until I.P.A. [i]. ${ }^{7}$ Although this feature was not specifically investigated, the recorded tokens allow to conclude that the dialect of Ğalbūn behaves like the majority of the Levantine dialects. The morpheme $-a$ is thus raised towards I.P.A. [e] unless it is preceded by an emphatic or a pharyngeal/laryngeal: samače "fish", gurfe "room", mačatte "ashtray", salle "basket", galläye "can for sweet coffee", rakabe "neck", mihrame "tissue". The low reflex occurs in the vicinity of gutturals, emphatics, and the emphatic allophone of /r/: kaddāha "lighter", wallāa a "lighter", bakara "cow", šağara "tree", tunğara țanğaṛa "pot", xalāṣa "placenta". The phonetics and the phonology of $-a$ in Salti in contrast to Palestinian dialects has already been analysed in AL-WER 2002. Her conclusion is that while in raising dialects of Palestine, the default variant of $-a$ is /e/ and raising is blocked only after emphatics and back consonants, the dialect of Salt differs in both phonetics and phonology. Phonetically, the raised value of $-a$ is I.P.A. $[\varepsilon]$ and phonologically, raising occurs only when the morpheme is preceded by a coronal sound (AL-WER 2002: 69). This leads her to say that the default value of $-a$ in the dialect of Salt is /a/ and not /e/ as in raising Palestinian varieties. The data collected in Salt largely confirm this analysis. However, when going into details, things don't appear to be that clear-cut: raising of $-a$ is prevented after primary emphatics (/ș/, /ț/ and /d $/)$, back consonants $\left(/ \mathrm{h} /, I^{\prime} /, / \% /, / \mathrm{h} /, / \mathrm{g} /, / \mathrm{k} /\right.$ and $/ \mathrm{g} /$ ) and the labio-velar approximant /w/. Examples are gușsa "story", ġtẹtta "fog", lahd̆a "moment", ğiha "side", tadfi'a "heating", guț a "piece", dabīha "slaughtered animal", luġa "language", frēxa "little chick (or girl)", mimlaka "kingdom", xāšŭga "spoon" and sarwa "early morning". No instances of $[\varepsilon]$ could be found after these consonants. Raising occurs systematically after /t/, /d/, /s/, /z/, /t l/, /d $/, / \breve{s} /, / \check{c} /, / \check{\mathrm{g}} /, / \mathrm{n} /$ and $/ \mathrm{y} /$. These are all, as stated by AL-WER (2002: 69), coronal sounds. Examples are sitte "six", wahade "one (f.)", midrase "school", ğìze "marriage", talāte "three", nabde "segment", tōše "fight", birče "pool", lahğe "accent", tukkāne "shop" and mayye "water". Both values can be found after the following consonants: /b/, /m/, /f/, /l/ and /r/. Examples with raising after /b/ are ǧêbe "pocket", garībe "close (f.)", girbe "skin bottle", xațībe "fiancée", mrattabe "well-done". Examples without raising are 'agaba "Aqaba", maxtūba "engaged (f.)", gara ạba "kinship", bawwāba "gate". It is obvious from these tokens that raising is blocked after the velarised allophone of /b/ which appears mainly in the vicinity of another emphatic. Compare for that matter xațībe and maxtū $\bar{b} a$, both derived from the root $x-t-b$. The spread of the velarised feature of $/ t /$ toward $/ b /$ is blocked by $/ \overline{1} /$ in $x a t i \bar{b} b$, whereas in maxt $\bar{u} b a$, the back vowel / $\overline{\mathrm{u}} /$ allows the spread of emphasis. The vicinity of a back vowel is actually enough to prevent raising, even without the presence of an emphatic sound, as illustrated by the following pair: habbe "piece, grain" and hubba "kiss". Examples of

6 See GROTZFELD's contribution in FISCHER / JASTROW 1980: 181. However, some rural varieties of central and southern Palestine are known to be non-raising dialects (SEEGER 2009: 1). Examples from the first text presented by SEEGER are madinna "city, town", lā šag̀la wala 'amla "jobless", lukma "bite", ma' is-salāma "bye", zalama "man", ğizza "marriage", "ǐša "life" (SEEGER 2009: 6).

7 This is usually the case in Lebanese varieties. See for example ABU-HAIDAR 1979: 19 for the dialect of Baskinta. 
raising after /m/ are zalame "man", gadīme "old (f.)", čilme "word", lahme "meat", țārme "to have minced (f.)", rasme "drawing", xēme "tent". Examples without raising are huküma "government", hurma "woman", miḥkama "court", magsüma "divided (f.)", 'umūma "motherhood", muntadama "organised", ma"luma "known (f.)". It appears from these examples that raising after $/ \mathrm{m} /$ is only triggered in the vicinity of a front vowel. On the contrary, the proximity of a back vowel (here mainly / $\overline{\mathrm{u}} /$ ) seems to be enough to prevent raising. It is also worth noting that raising is blocked even with the non-velarised allophone of $/ \mathrm{m} /$, the vicinity of a back vowel being enough. Amongst the examples given above, only in muntadama is $/ \mathrm{m} /$ clearly emphatic because of /d. In mihkama, the absence of raising could be explained by the presence of $/ \mathrm{k} /$ that tends to drag the following /a/ to the back, which in turn blocks raising. Examples of raising after /f/ are šâyfe "who sees (f.)", diffe "bank", xatīife "kidnapped (f.)", muxālafe "fine", xilfe "offspring", laffe "walk, ride". Examples without raising are ma'rüfa "known (f.)", ġurfa "room", miggrăfa "ladle", iḍāfa "addition". It is also clear from these examples that $-a$ is raised after /f/ in a front vocalic context, while raising is blocked in back or emphatic context. The same goes for $/ \mathrm{r} / \mathrm{after}$ which $-a$ is raised when preceded /i// or /1/1: zììre "small (f.)", gașire "short (f.)", gādre "able (f.)", ğìre "neighbourhood", hașirre "mat", ğazìre "island", sīre "event". In other contexts, back or emphatic, raising does not occur: bandōra "tomato", mašhūra "known", hāāūra "little piece of land in front of a house", xtyāra "old (f.)", huğra "exodus", bagara "cow", lèra (also realised nêra in the traditional dialect of Salt) "pound". One will notice also that $/ \mathrm{r} /$ is very sensitive to velarisation. Only the presence of a preceding $/ \mathrm{i} /$ or $/ \overline{1} /$ will prevent it. Even the vicinity of the front vowel /e/e will not trigger raising (as in lêra). The case of /l/ is somewhat peculiar as raising always occurs in plain context, back or front, as shown in the following examples: tawīle "long (f.)", 'èle "family", baggāle "grocery store", tufüle "childhood", hamūle "clan". From the last two examples, one has to conclude that the vicinity of the back vowel $/ \overline{\mathrm{u}} /$ is not enough to trigger raising. The only cases of non-raising were found after dark /l/: $\dot{g} \bar{u} l a$ "ogress", šag xāla "aunt", armala "widow". The dark colour of /1/ obviously comes from the spread of the velarised feature of /ț/ and /ș/ in 'uțla and bașala, but in the other examples, phonetics cannot fully account for the emphasis of $/ 1 /$. It must be therefore considered a lexically conditioned feature.

We can thus conclude that in Salti, raising occurs consistently after coronal sounds, except $/ \mathrm{l} /$ and $/ \mathrm{r} /$. These two phonemes behave differently as far as velarisation is concerned. In the case of $/ \mathrm{r} /$, the vicinity of a back vowel is enough to trigger velarisation, and therefore to block raising, whereas in the case /l/, only the vicinity of another emphatic will trigger a dark /l/ (except when / $/ 1 /$ is lexically conditioned), the proximity of a back vowel alone being insufficient to prompt raising. In the case of labials $(/ \mathrm{b} /, / \mathrm{m} /$, and $/ \mathrm{f} /$ ), raising occurs only when preceded by a front vowel.

CANTineAU $(1940,1946)$, in his description of Ḥōrāni dialects, doesn’t devote a separate chapter to the phonetics of $-a$, but data from different parts of his work allow to get a fairly clear picture of the different realisations of the feminine ending. He uses the concept of tafkim (in his own spelling) developed by medieval Arab grammarians to account for the raising of $-a$. Tafkim roughly refers to velarisation or emphasis. He distinguishes between consonants that are "mufakkama par nature" and others that are "mufakkama par position" (CANTINEAU 1946: 86). Consonants that are mufakkama par 
nature are $/ \mathrm{w} /, / \mathrm{k} /, / \mathrm{g} /, / \mathrm{x} /(\underline{\mathrm{k}}$ in CANTINEAU's spelling) and of course the three emphatics $/ \mathrm{s} /, / \mathrm{t} /$ and $/ \mathrm{d} /$. Consonants that are mufakkama par position are the three labials $/ \mathrm{b} /, / \mathrm{m} /$ and /f/, the two liquids /r/ and /l/, the two pharyngeals $/ \mathrm{h} /$ and /// and the laryngeal $/ \mathrm{h} /$. The main characteristic of the tafkim is to prevent imāla (raising). This is to say that $-a$ will not be raised after mufakkama consonants and that raising will occur only after non-mufakkama consonants (called by CANTiNEAU muraqqaqa). These are /t/, /d/, /s/, /z/, / $/ \mathrm{t} /, / \mathbf{d} /, / \breve{s} /, / \check{c} /, / \breve{g} /$, $/ \mathrm{n} /$ and $/ \mathrm{y} /$, which correspond exactly to the inventory of coronal sounds after which raising does not occur in Salti. As far as the tafkim par position is concerned, CANTINEAU notes that it can be triggered by "le voisinage d'une autre consonne emphatique ou mufakkamaou bien le voisinage d'une voyelle postérieure" ("the vicinity of another emphatic or mufakkama consonant, or the vicinity of a back vowel", CANTINEAU 1946: 86). This is also equivalent to the phonetic context needed in Salti to prompt raising after labials and liquids. What is different is CANTINEAU's inclusion of $/ \mathrm{h} /, /$ / and $/ \mathrm{h} /$ in the mufakkama par position. He writes however that in some parts of Hōrān (Ğēdûr, parts of eastern Zāwiye), /h/ and /'/ are mufakkama par nature (CANTINEAU 1946: 128). The case of /h/ is somewhat puzzling because in his chapter about the laryngeal /h/ (CANTINEAU 1946: 133-136), CANTINEAU only gives examples of the $3 \mathrm{fs}$ clitic $-h a$ realised -he in plain context, and no examples of $/ \mathrm{h} /$ followed by $-a$. However, tokens recorded in 'Ağlūn (Jordanian Ḥōrān) given to us by Enam AL-WER (p.c, 2010) clearly confirms that $-a$ is never raised after $/ \mathrm{h} /$. We can therefore conclude that Salti behaves exactly like Hōorāni as far as raising of $-a$ is concerned, while rural Palestinian dialects are either non-raising, or follow the common Levantine pattern.

\section{Morphology}

\subsection{Nominal morphology}

As far as morphology is concerned, an interesting point is the treatment in each dialect of ${ }^{*} \mathrm{CaC} \bar{i} \mathrm{C}$ and ${ }^{*} \mathrm{CaCūC}$. Here again it looks as if Salti was somehow between Ḥōrān and Palestine, $\mathrm{CaC}_{\overline{1} \mathrm{C}}$ being mostly common in Ḥōōān, whereas in Ğalbūn, $\mathrm{CC} \overline{\mathrm{I}} \mathrm{C}$ is more often encountered:

\begin{tabular}{|c|c|c|c|c|c|c|c|}
\hline & "stingy" & “old" & "long" & "breakfast" & "raisin" & "new" & "many" \\
\hline Ḥōrān & baxīl & gadīm & țawīl & fațūr & $z a b \bar{\imath} b$ & gadīd & $k / c ̌ c t i \bar{r} r$ \\
\hline Salt & baxīl & gadìm & tawìl & fațurr & $z a b \bar{i} b \sim z b \bar{l} b$ & $\check{g} d \bar{\imath} d$ & $k \underline{t} \underline{i} r$ \\
\hline Ǧalbūn & baxìl & kadìm & $t w \bar{l} l$ & fțūr & $z b \bar{\imath} b$ & ğdìd & $\stackrel{c}{c} \underline{t} \underline{i} r$ \\
\hline
\end{tabular}

The same goes for the vowel /u/ which appears mostly in Ḥōrān, less in Salt and less in Ğalbūn: 


$\begin{array}{llllll} & \text { "mouth" } & \text { "knee" } & \text { "mother" } & \text { "butter" } & \text { "cheese" } \\ \text { Ḥōrān } & \underline{\text { tumm }} & \text { rukba } & \text { 'umm } & \text { zubde } & \text { ğubne } \\ \text { Salt } & \underline{\text { tumm }} & \text { rukba } & \text { 'umm } & \text { zibde } & \text { ğibne } \\ \text { Ğalbūn } & \underline{\text { timm }} & \text { ričbe } & \text { 'imm } & \text { zidbe } & \text { ǧibne }\end{array}$

\subsection{Free and bound pronouns}

The pronominal paradigms in the three varieties are quite similar. Here are the paradigms of the independent pronouns:

\begin{tabular}{|c|c|c|c|c|c|c|c|c|}
\hline Ḥōrān & ani & $\operatorname{int}(e)$ & inti & $\begin{array}{l}h u w w a \\
\sim h \bar{u}\end{array}$ & $\begin{array}{l}\text { hiyye } \\
\sim h \bar{l}\end{array}$ & intu & intin & huṃma \\
\hline Salt & ana & $\operatorname{int}(e)$ & inti & $\begin{array}{l}\text { huwwa } \\
\sim h \bar{u}\end{array}$ & $\begin{array}{l}\text { hiyye } \\
\sim h \bar{\imath}\end{array}$ & intu & intin & hитти \\
\hline Ğalbūn & ana & inte & inti & $h \bar{u}$ & $h \bar{\imath}$ & intu & intin & humme \\
\hline
\end{tabular}

The main formal difference is ani for the 1s in Ḥōāni, whereas both Salti and Ğalbūni have ana. However, at closer scrutiny and although ana is the unmarked variant in Salt, ani also surfaces, most notably in pragmatically marked sentence types such as exclamatory or interrogative:

ani 'ärif čêf id-dinya rāhat?
I knowing how the-world went
"What do I know how the world became?"

Here again it seems that Salti is between Hōrāni and rural Palestinian. Another formal difference appears in the 3mp: huṃma (Hōōān), hummu (Salt) and humme (Ğalbūn), with once again a velarised reflex in Ḥōrān. A striking feature of the dialect of Ğalbūn is that it lacks the long forms huwwa and hiyye (rejected altogether by the consultant). One should note also that all these sedentary dialects kept a gender distinction in the $2^{\text {nd }}$ and $3^{\text {rd }}$ plural. We may therefore wonder whether the best way to account for the maintenance of this distinction is through a potential Bedouin influence, as advocated in PALVA 1994, or simply consider it an inherited feature. It should be noted however that in one of his last articles the same author did not consider this a Bedouin influence anymore but a "conservative and locally restricted" feature (PALVA 2008: 60, 64). The paradigms of the bound pronouns are quite similar in the three varieties. One difference arises in the $2 \mathrm{mp}$ : $k u$ in Salt and - $k u m$ in Ğalbūn. According to CANTINEAU, the form mainly encountered in Ḥōrān is -kom, although -ko was found in the Transjordanian locations he investigated (CANTINEAU 1946: 201). The form $-k u$ is not unknown in Palestine as it can be found for 
example in the dialect of Hebron (SEEGER 1996: 66). Therefore, this feature cannot be used as an isogloss. The feminine form -čin is shared by the three varieties (transcribed -čen ${ }^{n}$-or $-k e n^{n}$ without affrication by CANTINEAU 1946).

\subsection{Verbal morphology}

Since we deal here with three rural Levantine varieties, it comes as no surprise that they share much of their verbal morphology, most notably the maintenance of gender distinction in the $2^{\text {nd }}$ and $3^{\text {rd }}$ plural. The morphology of the perfective and the imperfective is identical in the three dialects, as exemplified below with the verb libis "to get dressed, wear":

$\begin{array}{lll} & \text { Perfective } & \text { Imperfective } \\ 1 \mathrm{~s} & \text { lbis- } t & \text { a-lbas } \\ 1 \mathrm{p} & \text { lbis-na } & \text { ni-lbas } \\ 2 \mathrm{~ms} & \text { lbis- } t & \text { ti-lbas } \\ 2 \mathrm{fs} & \text { lbis-ti } & \text { ti-lbas-i } \\ 2 \mathrm{mp} & \text { lbis-tu } & \text { ti-lbas- } u \\ 2 \mathrm{fp} & \text { lbis-tin } & \text { ti-lbas-in } \\ 3 \mathrm{~ms} & \text { libis } & y i \text {-lbas } \\ 3 \mathrm{fs} & \text { libs-at } & \text { ti-lbas } \\ 3 \mathrm{mp} & \text { libs- } u & y i-\text {-lbas- } u \\ 3 \mathrm{fp} & \text { libs-in } & y \text {-lbas-in }\end{array}$

\section{$3.4 \mathrm{C}_{1}$ is weak}

There is usually a great deal of cross-dialectal variation as far as weak verbs are concerned. On the one hand some varieties show the old pattern attested in classical Arabic in which $\mathrm{C}_{1}$ was usually dropped in the imperfective (wașala-yașilu "to arrive") while on the other hand other varieties maintain the weak element. This is generally the case in the urban dialects of the Levant where one can hear things like yūssal or yiwșal "he arrives". Ğalbūni, Salti and Hōōanni all belong to the first type. The verbs recorded in Ğalbūni are the following: wiki-yika' "to fall", wikif-yikaf "to stand up", wirim-yiram "to swell", wirityiriț yirat "to inherit", wișil-yișal "to arrive", yibis-yibas "to get dry". Similar data were recorded in Salt, except the first two verbs that are realised wigi'-yiga' (yigi' was also recorded) and wigif-yigaf. However, along these, some variation in the vowel of the pronominal prefixes was observed and /a/ can be heard instead of /i/. So equally possible are the forms yaga', yagaf, yaram, yarit, yașal, and yabas. As for Hōōān, CANTINEAU (1946: 234-235) says that although the situation is quite complex, the most widespread 
imperfective type is the /a/ type and gives forms like bașal "I arrive or he arrives", ptașal "you arrive", mnașal "we arrive". These forms are given with the indicative prefix $b$ - so corresponding forms in Salt would be bașal, btașal (initial /b/ is also devoiced through contact with adjacent /t/) and mnașal. Corresponding forms in Ğalbūn are bașal, btișal and mnișal. It should be added that in Ğalbūn, bașal stands only for the $1^{\text {st }}$ person singular, the $3^{\text {rd }}$ person singular being biṣal. This is also a striking feature shared by Salti and Ḥōāni in which there is homophony in the $1^{\text {st }}$ and $3^{\text {rd }}$ person singular for the $b$-imperfective of this kind of verbs. This is due to the fact that in most southern Levantine varieties, /y/ is dropped when $b$ - is prefixed:

Salti and Hōōāni:

$$
\begin{array}{llll}
1^{\text {st }} \text { person } & b-+ \text { așal } & \rightarrow & \text { bașal } \\
3^{\text {rd }} \text { person } & b-+ \text { "I arrivel } & \rightarrow & \text { baṣal }
\end{array}
$$

Ğalbūni:

$$
\begin{array}{lll}
1^{\text {st }} \text { person } & b-+ \text { așal } & \rightarrow \text { bașal "I arrive" } \\
3^{\text {rd }} \text { person } & b-+y i s ̦ a l & \rightarrow \text { biṣal "he arrives" }
\end{array}
$$

In conclusion, the pre-radical vowel in Ğalbūni is /i/, /a/ in Ḥōrāni and /a/ or /i/ in Salti.

\subsection{Form IV}

What is called form IV in Arabic grammar is the stem aCCaC (classical Arabic 'aCCaCa: xarağa "to get out" - 'axrağa "to take out") that gives a causative meaning to a root. Its retention in contemporary dialects is usually considered a conservative feature, since in many varieties it disappeared in favour (mainly) of form II CaCCaC. The Ğalbūni consultant did not recognise its existence in his native dialect, not even in the speech of the elders; he simply said he had never heard such a thing. It seems then that in Galbūni, the causative verbal derivation has been taken over by form II, leading to the maintenance of just a couple of lexical remnants of form IV such as at ta-yat ti or anta-yinti "to give". This non-occurrence of form IV in Ğalbūni, although it can be considered a "conservative dialect", is not something totally surprising since the same phenomenon can be observed in other "conservative" sedentary dialects. In his short article about the dialect of Karak (southern Jordan), PALVA 1989 does not even mention the existence of form IV, which can lead us to conclude that this form is not productive anymore in Karak, although Karaki can be labelled, to a certain extent, a "conservative" sedentary dialect: it kept the interdendals $/ \underline{\mathrm{t}} /, / \underline{\mathrm{d}} /$, , and $/ \underline{\mathrm{d}} /, / \mathrm{g} /$ is affricated and it maintains a gender distinction in the $2^{\text {nd }}$ and $3^{\text {rd }}$ plural persons.

On the contrary, the stem (a)CCaC was recorded in Salt. One of its functions, as suggested by the recorded tokens, is to create transitive verbs from nouns and adjectives whose roots are not attested in the simple verbal stem CvCvC. Examples are b'ad-yib'id "to

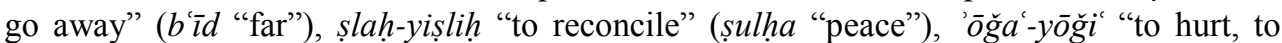
pain" (wağ(i) "pain"), 'ogad-yōgid "to light (a fire)" (classical Arabic waqūd "fuel”), ftar- 
yifțir "to have breakfast" (fațūr "breakfast"), 'ōda-yōdi "to lighten" (daww "light"). Form IV is also used in traditional Salti for "weather" verbs (these only appear in the feminine because the underlying subject dinya "world" is feminine): štat-tišti "to rain", grrabat-tigrib "to get dark", tlağat-titliğ "to snow". Another interesting characteristic of form IV is its specialisation to derive causative verbs from intransitive verbs whose stem is $\mathrm{CvCvC}$ (and thus making them transitive): g'ad-yig'id "to wake up" (ga'ad-yug'ud "to sit down"), z'alyiz'il "to upset" (za'al-yiz'al "to get upset", țla'-yițli "to take out" (tala'-yitla' "to go

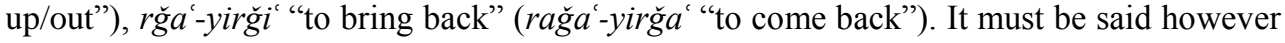
that this stem is dying out, probably because of the pressure exerted by the dialect of Amman in which form IV merged with form I ( $\mathrm{CvCvC})$ or II $(\mathrm{CaCCaC})$. It can now only be heard in the speech of the broadest speakers. The situation described by CANTINEAU for the dialects of Hōrān (CANTINEAU 1946: 259-262), as one might have guessed by now, is fairly similar to what was recorded in Salt. The majority of the forms recorded in Salt are also mentioned by CANTINEAU (in his transcription): $e b^{\prime} a d$ "to get away or move away" (only the first meaning was recorded in Salt), etlağat "to rain", äțla "to take out", ețlag "to release", eftar "to have breakfast", eg'ad "to wake up", 'óga "to hurt", 'ógad "to light". It must be noted nevertheless that the Hōorāni data gathered by CANTINEAU in the thirties of last century and contemporary Salti data show dissimilarities in terms of productivity: while there are clear indications that form IV is recessive in Salt, CANTINEAU (1946: 260) indicates that he was able to record a lot of these verbs, showing that it was still very productive in Ḥōrān back in the thirties.

\section{Conclusion}

The features discussed here are strong evidence that the dialect of Salt, which can be considered a typical example of central sedentary Jordanian, is essentially Ḥōrāni. As far as phonology is concerned, the most convincing traits are the common distribution of $/ \check{c} /$ and the realisation of the feminine ending $-a$. The proximity between Salti and Hōorāni is also further illustrated by shared assimilations, most notably the assimilation of $/ \mathrm{h} /$ to a preceding voiceless consonant at morpheme boundaries. In verbal morphology, a striking feature is the maintenance, in both Salti and Hōrāni, of form IV, which disappeared from other "conservative" sedentary dialects (i.e. Ğalbūni and Karaki). There are however a few features in which Salti and Ḥōrāni differ. These are secondary velarisation, the quality of the epenthetic vowel, reflexes of ${ }^{*} \mathrm{CaCi} C$, the distribution of the vowel $/ \mathrm{u} /$, the free and bound pronouns and the pre-radical vowel of the imperfective of weak verbs. As far as secondary velarisation, reflexes of ${ }^{*} \mathrm{CaCi} \mathrm{C}$, the pre-radical vowel of the imperfective of weak verbs and the distribution of the vowel /u/ are concerned, it was shown that Salti is always halfway through between Hōōanni and rural Palestinian. While secondary emphasis is very common in Ḥōrān and almost inexistent in rural Palestinian (apart from /ṛ/), Salti is in between. The same goes for ${ }^{*} \mathrm{CaC} \overline{1} \mathrm{C}$ which is very common in Ḥōrān, less in Salt and even less in Ğalbūn. The distribution of / $\mathrm{u} /$ is another example of this scale: widespread in

8 This, however, does not work with roots whose second consonant is weak. In this case, stem II $\mathrm{CaCCaC}$ will be favoured: layyalat id-dinya "it got dark" (lēl "night"). 
Ḥōrān, less in Salt, and even less in Ğalbūn. Concerning the pre-radical vowel of weak verbs, it also looks as if Salt was somewhere between Palestine and Hōorān, displaying features from both areas. As far as free pronouns are concerned, the landmark of Hōorāni in comparison to other varieties is the $1^{\text {st }}$ person singular ani, whereas most southern Levantine varieties have ana. In Salt, one hears most often ana, while ani seems to be restricted to marked sentence types. One feature though that behaves like in Palestinian varieties is the quality of the epenthetic vowel. It appears from this that while Salti is at its core Hōrāni, it has also been influenced by varieties from the other side of the Jordan River. This could explain the loss or partial loss of typical Ḥōāni features in the dialect of Salt, such as secondary velarisation, quality of epenthetic vowels, vowel $/ \mathrm{u} /$, stem $\mathrm{CaCīC}$, or the form ani. This claim is rather natural when one looks at history as it is well documented that Salt was in close contact with cities of the West-Bank, most notably Nāblis (see for that matter SALIBI 1993: 35-37). There are of course many features still that could be taken into account to further exemplify similarities and differences between Salti, Ḥōrāni and Ğalbūni. One might argue of course that the selection of features will always remain arbitrary and the proximity between these dialects will always seems somewhat impressionistic, depending on the selected features. To solve this issue, 341 features out of BEHNSTEDT's (1997) linguistic atlas of Syria where data were available in the three dialects were selected and compared systematically. The percentages of shared features between the different varieties are the following:

$\begin{array}{ll}\text { Salti-Hōorāni } & 85.9 \% \\ \text { Salti-Ğalbūni } & 77.7 \% \\ \text { Ḥōrāni-Ǧalbūni } & 69.2 \%\end{array}$

This shows that according to the statistics, the dialect of Salt share more affinities with Ḥōrāni than with Ğalbūni. This supports the conclusion that Salti is at its core Ḥōrāni, but through contact with Palestinian varieties, some Ḥōrāni features were lost or confined to a more restricted usage, as in the case of ani vs. ana. A quick incursion into the lexicon actually also confirms this. Indeed, Salti has a certain number of doublets. Examples are items like (a)mēt "when", typically Hōorāni, alongside with wēnta, a form that is also found in Ğalbūn. The same goes for $\dot{g} a d(d)$ and bukra. The form $\dot{g} a d(d)$ is typically Ḥōrāni and means "tomorrow". Galbūni only has bukra while Salti has both. It seems however that in Salt, bukra is restricted to "tomorrow", while $\dot{g} a d(d)$ is used mainly in the sense of "in the future". Another striking example is the three different forms recorded in Salt for the genitive exponent. Alongside the traditional Levantine taba, one can also hear šiyy- and giyy-, the latter being the original Ḥōrāni form. Such a diversity is best explained by contact. No traces of siyyy-could be found in other varieties. The closest form is šit which can be found in Palestine (CLEVELAND 1963: 61-62) and in the old dialect of Damascus (LENTIN 2006: 552) ${ }^{9}$ but it does not inflect for number and gender, unlike Salti šiyy- (šizy-, šit - , šiyyin and šiyyāt). It is therefore very likely that šiyy is the outcome of the merging of

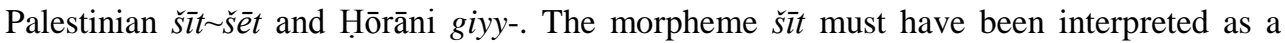
feminine form, and then a new paradigm arose, modelled on giyy- which also inflects for gender and number (giyy, gìt, giyyin and giyyāt). There is does compelling phonological,

9 LENTIN 2006 also gives the variant šiyāt but like šìt, it's not marked for gender or number. 
grammatical and lexical evidence that Salti should be seen as a Hōrāni dialect with a Palestinian adstrate. It is now possible to go back to the initial question: do Jordanians speak like Palestinians? The answer is that, although Jordanian varieties and Palestinian varieties are of the southern Levantine type, sedentary Jordanian dialects south of Hōrān are clearly best viewed as offshoots of Ḥōrāni dialects, and do not originate from Palestine.

\section{Bibliography}

ABU-HAIDAR, F. 1979. A Study of the Spoken Arabic of Baskinta. Brill, Leiden.

AL-WeR, E. 2002. "Jordanian and Palestinian Dialects in Contact: Vowel Raising in Amman". In: JONES / ESCH (eds.) 2002: 63-79.

AL-Wer, E. 2007. "The Formation of the Dialect of Amman". In: Mille [et al.] (eds.) 2007: 55-76.

AL-Wer, E. / Herin, B. 2011. "The Life-Cycle of Qaf in Jordan”. Langage et société, 138: 59-76.

BANi-YAsin, R. / Owens, J. 1987. "The Phonology of a Northern Jordanian Arabic Dialect". Zeitschrift der Deutschen Morgenländischen Gesellschaft, 137,2: 297-331.

Behnstedt, P. 1997. Sprachatlas von Syrien. Kartenband. Harrassowitz, Wiesbaden.

BergSträSSER, G. 1915. "Sprachatlas von Syrien und Palästina". Zeitschrift des Deutschen Palästina-Vereins, 38: 169-222.

CAntineau, J. 1940. Les parlers arabes du Hōrān. Atlas. Klincksieck, Paris.

CANTineau, J. 1946. Les parlers arabes du Hōrāann. Notions générales, grammaire. Klincksieck, Paris.

Caubet, Dominique / Vanhove, Martine (eds.). 1994. Actes des premières journées internationales de dialectologie arabe de Paris. INALCO, Paris.

Cleveland, R. 1963. "A Classification for the Arabic Dialects of Jordan". Bulletin of the American Schools of Oriental Research, 171: 56-63.

FISCHER, W. / Jastrow, O. 1980. Handbuch der arabischen Dialekte. Harrassowitz, Wiesbaden.

HAAK, Martine / DE JONG, Rudolf / VersteEgh, Kees (eds.). 2004. Approaches to Arabic Dialects. A Collection of Articles Presented to Manfred Woidich on the Occasion of His Sixtieth Birthday. Brill, Leiden.

Herin, B. 2010. Le parler arabe de Salt (Jordanie). Phonologie, morphologie et éléments de syntaxe. Ph.D. thesis, Université Libre de Bruxelles, Brussels.

JONES, Mari / Esch, Edith (eds.). 2002. Language Change. The Interplay of Internal, External and Extra-linguistic Factors. Mouton de Gruyter, Berlin.

LENTIN, J. 2006. "Damascus Arabic". In: Encyclopedia of Arabic Language and Linguistics, 1: 546555.

Mille, Catherine / Al-Wer, Enam / Caubet, Dominique / Watson, Janet C.E. (eds.). 2007. Arabic in the City. Issues in Dialect Contact and Language Variation. Routledge, Londonc and NewYork.

Palva, H. 1984. "A General Classification for the Arabic Dialects Spoken in Palestine and Transjordan". Studia Orientalia, 55: 359-376.

Palva H. 1987. "Linguistic Sketch of the Arabic Dialect of El-Karak". In: WeXler / BORG / SOMEKH (eds.) 1987: 225-251.

Palva, H. 1992. "Typological Problems in the Classification of Jordanian Dialects. Bedouin or Sedentary?” In: UTAS / VIKOR (eds.) 1992: 53-62.

Palva, H. 1994. "Bedouin and Sedentary Elements in the Dialect of es-Salt. Diachronic Notes on the Sociolinguistic Development”. In: CAUBET / VANHOve (eds.) 1994: 459-469. 
Palva, H. 2004. "Negations in the Dialect of es-Salt, Jordan". In: HaAK / De Jong / Versteegh (eds.). 2004: 221-236.

Palva, H. 2008. "Sedentary and Bedouin Dialects in Contact. Remarks on Karaki and Salti Dialects (Jordan)". Journal of Arabic and Islamic Studies, 8: 53-70.

SALIBI, K. 1993. The Modern History of Jordan. I.B. Tauris, London.

SEEGER, U. 1996. Der arabische Dialekt von il-Xalīl (Hebron). MA thesis, University of Heidelberg. SEEger, U. 2009. Der arabische Dialekt der Dörfer um Ramallah. Teil 1: Texte. Harrassowitz, Wiesbaden.

UtAS, Bo / ViKor, Knut S. (eds.). 1992. The Middle East Viewed From the North. Papers from the first Nordic conference of Middle Eastern Studies, Uppsala 26-27 January 1989. Nordic Society for Middle Eastern Studies, Bergen.

Wexler, Paul / Borg, Alexander / SomeKh, Sasson (eds.). 1987. Studia Linguistica et Orientalia Memoriae Haim Blanc Dedicata. Otto Harrassowitz, Wiesbaden.

Bruno Herin, Université Libre de Bruxelles, Faculté de Philosophie et Lettres - Langues et Littératures (unité ULB720), Belgium

$\triangleleft$ bruno.herin@ulb.ac.be 